\title{
Prasangka Mahasiswa Papua Pada Etnis Jawa Di Kota Malang
}

\author{
Klaudia Ulaan, Ika Herani, \& Intan Rahmawati \\ kla_ulaan@yahoo.co.id
}

\section{Program Studi Psikologi, FISIP, Universitas Brawijaya, Malang, Indonesia}

\begin{abstract}
Indonesia adalah sebuah negara yang memiliki keragaman etnis. Keragaman ini membawa Indonesia sering dihadapkan pada berbagai permasalahan di antaranya adalah adanya prasangka. Prasangka juga berkembang pada masyarakat Papua dan Jawa. Prasangka antar kedua etnis membawa penelitian ini mengungkapkan prasangka pada mahasiswa asli Papua yang melanjutkan penelitian di kota Malang, di mana mahasiswa Papua yang memiliki prasangka harus hidup dan bersosialisasi dengan masyarakat etnis Jawa yang mendominasi kota Malang. Penelitian ini menggunakan metode kualitatif dengan pendekatan fenomenologi. Subjek dalam penelitian ini adalah 5 mahasiswa Papua yang memiliki prasangka pada masyarakat etnis Jawa. Teknik pengumpulan data adalah observasi non partisipan dan wawancara semi terstruktur. Teknik analisis menggunakan model Miles dan Huberman. Berdasarkan hasil penelitian, diketahui sumber prasangka yang berbeda antar subjek. Hal ini dikarenakan berbedanya pengalaman dan cara pandang masing-masing subjek. Dalam tipe prasangka, dua subjek tergolong tipe aversive dan tiga subjek tergolong tipe ambivalent. Dampak prasangka yang dimiliki keempat subjek memiliki kesamaan yaitu pengucilan sosial dan adanya konflik sosial yang berbeda bentuk satu sama lainnya. Dampak prasangka pada kelima subjek juga menjelaskan adanya jarak sosial antara mahasiswa Papua dengan masyarakat etnis Jawa.
\end{abstract}

Kata kunci : prasangka, mahasiswa papua, masyarakat etnis jawa

Indonesia adalah sebuah negara yang memiliki keragaman etnis. Menurut Jawa Pos National Network, hasil sensus penduduk, diketahui bahwa Indonesia terdiri dari 1.128 etnis (Afiz, 2010). Menjadi negara dengan banyak keberagaman etnis adalah tidak mudah karena cenderung dihadapkan pada permasalahan antar etnis. Indonesia yang merupakan negara multikultural memiliki berbagai konflik sosial yang melibatkan berbagai etnis. Bila dilihat dari perkembangan sejarah menurut Puspa (2011), konflik biasanya terjadi antara golongan pribumi dari etnis Tionghoa dan golongan non pribumi yaitu masyarakat asli Indonesia, meskipun untuk saat ini mengalami pergeseran dengan bertambahnya konflik antar etnis. Sebagai contoh konflik antar etnis Madura dan Dayak. Setidaknya telah terjadi dua kali kerusuhan berskala besar antara kedua suku ini, yaitu peristiwa Sampit pada tahun 2001 dan Senggau Ledo pada tahun 1996. Kedua kerusuhan ini merembet ke hampir semua wilayah Kalimantan dan berakhir dengan pengusiran dan pengungsian ribuan warga Madura, dengan jumlah korban 
hingga 500 orang. Konflik serupa juga terjadi di Tanah Ambon, di mana terjadi pengusiran terhadap etnis Bugis, Buton, dan Makassar (BBM). Pertikaian di Ambon, terlebih dahulu dipicu oleh kondisi perekonomian, di mana masyarakat pendatang yang terdiri dari etnis Bugis, Buton, dan Makassar lebih menguasai dan lebih berperan dibandingkan orang Ambon sendiri. Keadaan yang demikian menimbulkan kesenjangan orang Ambon, di mana mereka merasa kalah di tanah sendiri oleh pendatang dan hal ini juga yang pada akhirnya menimbulkan prasangka mayoritas-minoritas (Mendatu, 2007).

Prasangka yang terjadi antara pendatang dengan penduduk lokal yang berakhir pada konflik salah satunya adalah masyarakat etnis Jawa yang bertransmigrasi ke tanah Papua. Dalam penelitian Mulyadi (dalam Putra, 2012), bagi masyarakat Papua, para pendatang, khususnya pendatang Jawa dipandang sebagai penjajah. Bahkan mereka mereduksi kategori pendatang pada mereka yang berambut lurus. Lebih sempit lagi, pendatang yang berambut lurus digambarkan oleh orang asli Papua sebagai orang Jawa. Terkadang mereka memanggil orang Jawa dengan "amber" sebagai bentuk pengategorian kelompok yang dibenci. Menurut pandangan mereka, orang Jawa telah menguasai sebagian perekonomian di Papua.

Kesenjangan sosial yang terjadi di Papua tersebut membawa prasangka masyarakat lokal yaitu masyarakat Papua terhadap masyarakat pendatang, sehingga apabila terjadi kejadian negatif, sebagai contoh menabrak babi, atau pun terjadi pencurian, sering kali masyarakat pendatang yang salah satunya adalah masyarakat Jawa yang menjadi sasaran utama. Namun kenyataannya, tidak semua tindak kejahatan selalu dilakukan oleh masyarakat pendatang (Interview awal dengan Yiswi penduduk Jawa yang bekerja di Papua, September 2012).

Fenomena yang terjadi antara kedua etnis ini, yaitu Papua dan Jawa pada akhirnya menghadirkan prasangka. Menurut Levy dan Hughes (dalam Putra, 2012), prasangka sejatinya adalah fenomena yang hadir dalam hubungan antar kelompok, bukan antar individu. Individu yang menjadi target prasangka adalah individu yang menjadi bagian dari kelompok, bukan karena karakteristik individu itu sendiri. Individu disimplifikasi ke dalam satu kesatuan karakteristik yang sama dengan kelompoknya. Sama halnya dengan penduduk pendatang dari Jawa di Papua.

Prasangka dikategorikan ke dalam tiga tipe oleh Geartner, Jones, dan Kovel (dalam Soeboer, 1990). Pertama, tipe dominative di mana individu dalam tipe ini akan secara terbuka mengekspresikan prasangkanya dan melakukan tindakan berupa penyerangan. Kedua, tipe ambivalent di mana individu dalam tipe ini akan mengekspresikan perasaan tidak sukanya, namun di saat bersamaan individu dalam tipe ini juga merasa bersimpati kepada target prasangka. Ketiga, tipe aversive di mana individu dalam tipe ini bersikap positif namun sebenarnya berusaha sedapat mungkin untuk tidak berinteraksi dengan target prasangka.

Fenomena kesenjangan sosial antara Jawa dan Papua, berbanding terbalik dengan kondisi di Kota Malang yang notabene merupakan salah satu kota dari pulau Jawa, yang mana masyarakatnya dianggap kaum penjajah di pulau Papua. Kota Malang merupakan kota pendidikan 
di Jawa Timur yang memiliki beragam masyarakat yang tinggal di dalamnya. Sebagai salah satu kota pusat pendidikan, terdapat berbagai pendatang dengan latar belakang suku yang berbeda, termasuk di dalamnya pendatang dari Papua. Berdasar data yang dihimpun dari IMPAM (Ikatan Mahasiswa Papua di Malang) tahun 2012, terdapat sekitar tujuh ribu masyarakat asli Papua yang menetap di Malang, dengan kurang lebih dua ribu mahasiswa yang tersebar di berbagai perguruan tinggi yang ada.

Menurut Susetyo (dalam Puspa, 2011), etnis Jawa yang dikenal sebagai suku bangsa yang sopan dan halus bertutur kata diharapkan mampu membawa ajaran/budaya yang bersifat positif tersebut baik pada sesama etnis maupun etnis yang lainnya. Semakin lengkap dengan sifat yang dimiliki etnis Jawa yaitu kebiasaan mengukur (menerapkan) segala sesuatu dengan ukuran diri sendiri, yang berarti akan selalu menghargai orang lain, menjaga tutur kata agar tidak menyinggung orang lain, berperangai lembut karena menyadari bahwa hidup tidak mungkin sendiri. Dalam kondisi budaya Jawa yang demikian peneliti ingin melihat bagaimana prasangka yang berkembang pada pendatang yang difokuskan pada mahasiswa Papua. Bertolak dari prasangka orang Papua terhadap orang Jawa di tanah Papua, peneliti berusaha melihat bagaimana prasangka mahasiswa Papua yang melanjutkan pendidikan di tanah Jawa.

Baron dan Byrne (2004) mendefinisikan prasangka sebagai sebuah sikap (biasanya negatif) terhadap anggota kelompok tertentu, semata berdasarkan keanggotaan mereka dalam kelompok tersebut. Ahli lain seperti Brehm dan Kassin (dalam Dayaksini dan Hudaniah,
2009) berpendapat bahwa prasangka adalah perasaan negatif yang ditunjukkan terhadap seseorang semata-mata berdasarkan pada keanggotaan mereka dalam kelompok tertentu.

Menurut Worchel, dkk. (dalam Mendatu, 2007), pengertian prasangka dibatasi sebagai sifat negatif yang tidak dapat dibenarkan terhadap suatu kelompok dan individu anggotanya. Prasangka atau prejudice merupakan perilaku negatif yang mengarahkan kelompok pada individualis berdasarkan pada keterbatasan atau kesalahan informasi tentang kelompok. Selanjutnya Augostinos dan Reynolds (dalam Sarwono, 2002), menjelaskan bahwa prasangka dapat disimpulkan sebagai upaya atau keinginan merendahkan individu atau kelompok lain.

Melalui beberapa pengertian yang telah disebutkan oleh beberapa ahli, prasangka merupakan suatu sikap yang cenderung negatif dalam menilai anggota kelompok tertentu tanpa mempertimbangkan faktafakta lainnya dan kemudian menggeneralisasikannya terhadap seluruh anggota kelompok.

Sarwono (2002) menjelaskan prasangka dapat bersumber baik pada interaksi sosial (hubungan antar kelompok) maupun pada proses yang terjadi dalam diri individu (dinamika kepribadian). Hal senada juga dikemukan dalam Myers (1988) bahwa prasangka memiliki beberapa sumber yang dapat digolongkan dalam tiga jenis. Pertama, sumber sosial, yang terbagi menjadi dua yaitu identitas sosial dan konformitas. Identitas sosial menurut Turner dan Tajfel (dalam Sarwono, 2007) menyatakan bahwa manusia melakukan kategorisasi, identifikasi, dan perbandingan di mana hal tersebut akan membagi dunia individu menjadi dua kategori yang berbeda, yaitu orang lain 
yang satu kelompok dengannya (ingroup) dan orang lain yang berbeda kelompok dengannya (outgroup). Anggota outgroup diasumsikan memiliki trait atau sifat yang kurang menyenangkan serta dipersepsikan semuanya memiliki kesamaan dan sering tidak disukai.

Kedua, sumber emosi, yang terbagi menjadi dua yaitu frustasi dan agresi serta kepribadian otoriter. Frustasi dan agresi menjelma ke dalam tindakan-tindakan diskrimnatif dan agresif terhadap target prasangka. Tindakan agresif tersebut diuraikan para ahli sebagai akibat dari adanya perasaan frustasi sehingga disebut dengan istilah frustasi agresi (Gerungan, 1988). Perihal agresi, menurut Dollard, dkk. (dalam Putra 2012), agresi terdiri atas berbagai bentuk penyampaian. Bentuk agresi ini dapat berbentuk fisik, misalnya pemukulan atau pun simbolik seperti kebencian atau rasa tidak suka. Sedangkan kepribadian otoriter merupakan emosi yang ikut berkontribusi terhadap prasangka.

Ketiga, sumber kognitif. Sumber kognitif pembentuk prasangka adalah stereotip yang merupakan kerangka kognitif yang berisi pengetahuan dan belief tentang kelompok sosial tertentu dan dilihat sebagai tipikal yang dimiliki oleh anggota kelompok tertentu. Individu yang memiliki stereotip tentang kelompok sosial tertentu akan melihat bahwa semua anggota kelompok sosial tersebut memiliki traits tertentu. Jika yang ditemuinya adalah informasi yang tidak konsisten dengan stereotip, maka akan diubah dengan cara yang halus agar tidak menimbulkan prasangka.

Dampak prasangka menurut Putra (2012) ada dua. Pertama, pengucilan sosial, yang dipahami sebagai pengucilan terus menerus dan gradual dari partisipasi secara penuh di dalam lingkungan sosial. Studi dalam psikologi telah menunjukkan dampak negatif dari pengucilan sosial, di antaranya adalah menurunkan perilaku prososial. Kedua, konflik sosial yang merupakan salah satu bentuk proses sosial yang disosiatif selain persaingan dan kontraversi akibat adanya perbedaanperbedaan tertentu dalam masyarakat maupun pribadi, seperti akibat perbedaan ras, suku bangsa, agama, adat istiadat, golongan politik, pandangan hidup, profesi, dan budaya lainnya.

\section{Metode}

\section{Desain Penelitian dan Partisipan}

Desain penelitian ini berangkat dari fenomena kasus antara masyarakat etnis Jawa dan orang Papua, sehingga pendekatan yang digunakan adalah fenomenologi. Dalam setiap hal, manusia memiliki pemahaman serta penghayatan terhadap fenomena yang dilaluinya. Pemahaman serta penghayatannya tersebut selanjutnya sangat berpengaruh pada perilakunya (Herdiansyah, 2010). Partisipan dalam penelitian ini terbagi menjadi lima orang mahasiswa Papua dengan kriteria memiliki prasangka pada masyarakat etnis Jawa dan subjek sekunder yang merupakan ibu pemilik indekos dan sahabat dari subjek primer.

\section{Teknik Pengumpulan Data dan Analisis Data}

Teknik pengumpulan data dalam penelitian ini adalah observasi non partisipan dan wawancara semi terstruktur pada sumber data primer dan sumber data sekunder. Teknik analisis data yang digunakan tehadap data-data yang sudah diperoleh menggunakan model Miles dan Huberman (dalam Herdiansyah, 2010) dengan melalui empat tahapan yaitu 
pengumpulan data, reduksi data, display data, dan kesimpulan.

\section{Hasil}

Berdasarkan hasil penelitian di lapangan, ditemukan bahwa keseluruhan subjek yang berprasangka pada masyarakat etnis Jawa memiliki sumber prasangka, penggolongan tipe prasangka, dan dampak prasangka yang berbeda satu sama lain. Perbedaan ini dikarenakan berbedanya pengalaman dan cara menyikapi masingmasing subjek.

\section{Sumber Prasangka}

Menurut Turner dan Tajfel (dalam Sarwono, 2007) manusia melakukan kategorisasi, identifikasi, dan perbandingan di mana hal tersebut akan membagi dunia individu menjadi dua kategori yang berbeda, yaitu orang lain yang satu kelompok dengannya (ingroup) dan orang lain yang berbeda kelompok dengannya (outgroup). Pengategorian ini merupakan sumber prasangka yang disebut dengan identitas sosial di mana dari semua subjek penelitian kecuali subjek JM mengalaminya. Subjek YM, YB, SS, dan $\mathrm{JH}$ memiliki pengategorian trait ingroup (sesama orang Papua) yang cenderung sama satu sama lain, yaitu memiliki nilai kasih yang besar sehingga selalu berusaha menghargai orang lain dengan bersikap ramah dan senang memberi salam tanpa melihat latar belakang dan bentuk fisik.

Pada pengkategorian trait outgroup, keempat subjek tersebut memiliki persamaan pandangan tetapi dengan bentuk yang berbeda. Perbedaan tersebut dipengaruhi oleh berbedanya pengalaman yang diterima masing-masing subjek dari masyarakat etnis Jawa. Adapun trait dari masyarakat etnis Jawa menurut subjek YM, YB, SS, dan JH adalah kurang menghargai orang Papua. Bagi subjek YM, masyarakat etnis Jawa kurang menghargai dirinya sebagai orang Papua. Hal itu nampak dari seringnya subjek YM dilihat dengan pandangan aneh dan sekaligus ditertawakan. Hal lainnya adalah tidak dianggapnya orang Papua sebagai bagian dari Indonesia. Senada dengan pandangan subjek YM, subjek YB pun merasakan bahwa dirinya sebagai orang Papua sering kali dilihat dengan pandangan aneh dan menakutkan serta apabila memberi salam kepada masyarakat etnis Jawa, memiliki kemungkinan tidak dibalas karena masyarakat etnis Jawa tidak seperti orang Papua yang senang saling menyapa satu sama lain. Lain halnya dengan subjek SS, trait kurang menghargai dari masyarakat etnis Jawa nampak dari kecenderungan tidak mau berbagi dengan orang Papua serta tidak memberi balasan yang baik ketika subjek SS sebagai orang Papua ingin mendekatkan diri dengan masyarakat etnis Jawa.

Bagi subjek JH, trait kurang menghargai dari masyarakat etnis Jawa nampak dari tidak terbukanya dan tidak ingin bersatunya masyarakat etnis Jawa dengan orang Papua. Berbeda dengan subjek YM dan YB, pengategorian trait outgroup pada subjek JH dan SS dikhususkan bagi masyarakat etnis Jawa yang tidak seiman dikarenakan bagi kedua subjek tersebut masyarakat etnis Jawa yang seiman berbeda. Dikatakan subjek SS masyarakat etnis Jawa seiman menghargai dirinya dengan mau menerima apa adanya tanpa melihat dari segi fisik dan bagi subjek JH masyarakat etnis Jawa seiman mau bersatu dengan orang Papua. Pada subjek JM, tidak ditemukan adanya pengkategorian trait yang adalah salah satu sumber terbentuknya prasangka. Hal ini dikarenakan bagi subjek JM masing- 
masing trait yang dimiliki baik oleh orang Papua maupun masyarakat etnis Jawa tidak membawa dirinya untuk mengategorisasikan dan memberi perbedaan atribut yang mengakibatkan subjek JM memiliki kecenderungan untuk memilih salah satu dari dua kelompok tersebut yaitu orang Papua dan masyarakat etnis Jawa. Subjek JM memaknai pengalaman kurang menyenangkan dari masyarakat etnis Jawa secara positif sehingga membawa dirinya tidak menjauhi masyarakat etnis Jawa.

Konformitas sebagai salah satu sumber sosial pembentuk prasangka tidak dimiliki oleh kelima subjek penelitian. Hal ini dikarenakan masing-masing subjek bisa menerima segala norma serta adat istiadat yang berlaku dengan baik. Menurut Feldman, konformitas adalah perubahan tingkah laku individu karena adanya keinginan untuk mengikuti keyakinan dan standar orang lain (Baron dan Byrne, 2002). Frustasi dan Agresi dimiliki kelima subjek penelitian. Perihal agresi, menurut Dollard, dkk. (dalam Putra, 2012), agresi terdiri atas berbagai bentuk penyampaian. Bentuk agresi ini dapat berbentuk fisik semisal pemukulan atau simbolik seperti kebencian atau rasa tidak suka. Hal ini pula yang terjadi pada masing-masing subjek penelitian dengan didasarkan pada pengalaman kurang menyenangkan dari masyarakat etnis Jawa yang berbeda satu sama lain. Masing-masing pengalaman membawa kelima subjek merasakan frustasi yang pada akhirnya membawa agresi yaitu perasaan benci ataupun tidak suka terhadap masyarakat etnis Jawa.

Kepribadian otoriter juga merupakan salah satu sumber emosi pembentuk prasangka. Kekhasan yang dimiliki oleh orang-orang yang berkepribadian otoriter adalah intoleran, menolak, dan membenci orang atau kelompok yang melanggar atau keluar dari nilai-nilai konsensional. Berdasarkan penelitian, kelima subjek tidak tergolong memiliki kepribadian otoriter. Hal ini juga dipengaruhi oleh identitas sosial dari orang Papua yang memiliki kasih yang besar dan tidak terbatas bagi siapapun. Oleh sebab itu walaupun memiliki perasaan benci ataupun tidak suka pada masyarakat etnis Jawa, masing-masing subjek tetap memiliki toleransi, tidak menaruh dendam, ataupun merasa superior.

Persamaan lainnya dari kelima subjek penelitian adalah adanya stereotip kepada masyarakat etnis Jawa yang merupakan sumber kognitif pembentuk prasangka. Menurut Meinarno (2009), stereotip adalah kepercayaan bahwa anggota kelompok tertentu memiliki karakteristik atau sifat tertentu.

\section{Tipe Prasangka}

Prasangka menurut Geartner, Jones, dan Kovel (dalam Soeboer, 1990) mengemukakan tiga tipe prasangka yaitu dominative, ambivalent, dan aversive. Ketiga hal tersebut dibedakan oleh masing-masing komponennya yaitu kognitif, afektif, dan konatif. Berdasarkan prasangka yang dimiliki oleh kelima subjek penelitian, masing-masing subjek tergolong dalam salah satu dari tipe prasangka tersebut. Subjek YM dan JM tergolong dalam tipe prasangka aversive di mana dalam aspek kognitif, kedua subjek memiliki kognisi bahwa bersikap baik dan ramah adalah suatu hal yang penting terlebih masing-masing subjek adalah orang Papua yang dikenal sebagai manusia yang penuh kasih walaupun sebenarnya memiliki rasa benci ataupun tidak suka terhadap masyarakat etnis Jawa yang merupakan perwujudan dari aspek afektif. 
Dalam aspek konatif terdapat perbedaan pada kedua subjek. Subjek YM mengurangi hubungan yang intim dengan masyarakat etnis Jawa. Sementara itu, subjek JM bukan hanya mengurangi pendekatan personal melainkan lebih luas lagi yaitu mengharapkan kemerdekaan, yang dalam hal ini berarti pemisahan dari pemerintahan Indonesia yang secara tidak langsung juga pemisahan dengan masyarakat etnis Jawa yang dianggap banyak merugikan orang Papua.

Pada ketiga subjek lainnya yaitu subjek YB, SS, dan JH, mereka semua tergolong dalam tipe prasangka ambivalent di mana masing-masing subjek meyakini kognisi bahwa berinteraksi dengan masyarakat etnis Jawa akan membawa suatu masalah. Subjek YB meyakini masalah tersebut adalah dengan dipandangnya orang Papua secara aneh dan menakutkan. Sementara itu, subjek SS dipandang kurang pintar dan selanjutnya subjek JH yang juga merasakan seperti subjek SS yaitu dipandang kurang pintar dan kasar. Pada aspek afektif pada dasarnya masing-masing subjek memiliki keinginan atau perasaan ingin mendekatkan diri dengan masyarakat etnis Jawa, tetapi karena kognisi akan keyakinan mendapat masalah pada akhirnya membawa rasa khawatir dan membuat ketiga subjek tersebut memilih untuk mengurangi interaksi dengan masyarakat etnis Jawa. Terdapat perbedaan bentuk penarikan diri masing-masing subjek terhadap masyarakat etnis Jawa yaitu pada subjek YB secara umum menyeluruh terhadap masyarakat etnis Jawa kecuali bapak dan ibu pemilik indekosnya sedangkan pada subjek SS dan JH dikhususkan pada masyarakat etnis Jawa yang tidak seiman.

\section{Dampak Prasangka}

Dampak prasangka menurut Idhamsyah dan Ardiningtiyas (dalam Putra, 2012) adalah adanya pengucilan sosial dan konflik sosial. Konflik sosial sendiri menurut Ahmadi (2007) memiliki beberapa bentuk yaitu konflik pribadi, konflik kelompok, konflik antar kelas sosial, konflik rasial, konflik politik, dan konflik budaya. Berdasarkan prasangka yang dimiliki kelima subjek, masingmasing memiliki dampak prasangka. Konflik sosial terjadi pada kelima subjek dengan bentuk yang berbeda. Pada subjek YM dan YB terjadi konflik berbentuk sosial pribadi dan pada subjek JM konflik berbentuk sosial politik dan sosial budaya. Selain konflik sosial keempat subjek kecuali subjek JM mengalami dampak prasangka yaitu pengucilan sosial. Pengucilan sosial ini tampak dari kurangnya interaksi dari masing-masing subjek terhadap pergaulan dengan masyarakat etnis Jawa. Keempat subjek cenderung tidak aktif dalam kegiatan organisasi maupun kegiatan masyarakat di lingkungan tempat tinggal. Masing-masing subjek lebih memilih untuk berkumpul dengan teman-teman sesama Papua, berdiam diri di indekos ataupun kontarakan serta mengikuti organisasi anak-anak Papua yang ada di Malang ataupun kegiatan yang bersifat religius seperti persekutuan di kampus dan gereja.

Berdasarkan data yang didapat peneliti, ditemukan kembali dampak dari prasangka yang juga dialami oleh masingmasing subjek yaitu terbentuknya jarak sosial antara mahasiswa Papua dengan masyarakat etnis Jawa. Menurut Mendatu (2007), jarak sosial adalah suatu jarak psikologis yang terdapat di antara dua orang atau lebih yang berpengaruh terhadap keinginan untuk melakukan 
kontak sosial yang akrab. Semakin besar prasangka yang timbul maka semakin besar jarak sosial yang terjadi.

\begin{abstract}
Kesimpulan
Pada penelitian ini, terdapat beberapa hal yang perlu untuk didiskusikan lebih lanjut yang nantinya dapat berguna bagi penelitian selanjutnya, seperti dalam hal aspek penelitian yang terlalu luas. Oleh karena itu, pada penelitian berikutnya dapat lebih difokuskan pada satu aspek yang lebih spesifik. Diharapkan pada penelitian selanjutnya dapat mengembangkan teori baru tersebut agar topik mengenai prasangka khususnya pada aspek dampak prasangka antara masyarakat etnis Jawa dan mahasiswa Papua yang melanjutkan pendidikan di pulau Jawa dapat lebih dimengerti secara mendalam.
\end{abstract}

\section{Daftar Pustaka}

Afiz. (2010). Indonesia Miliki 1.128 Suku Bangsa (online). http://www.jpnn. com/index.php?-mib =berita.detail\& $\mathrm{id}=57455$. Diunduh 5 Agustus 2012.

Ahira. (2000). Suku Jawa (online). http://www.anneahira.com/sukujawa.htm. Diunduh 12 September 2012.

Ahmadi, A. (2007). Psikologi Sosial. Jakarta: Rineka Cipta.

Gerungan, W. A. (1988). Psikologi Sosial. Bandung: Eresco.

Herdiansyah, H. (2010). Metodologi penelitian kualitatif untuk ilmu-ilmu sosial. Jakarta: Salemba Humanika.

Liliweri, A. (2005). Prasangka dan Konflik: Komunikasi Lintas Budaya Masyarakat Multikultural. Yogyakarta: LkiS.

Meinarno, E. (2009). Psikologi Sosial. Jakarta: Salemba Humanika.

Mendatu, A. (2007). Prasangka dalam Konflik Antar Etnik (online). http://smartpsikologi.blogspot.com/2 007/08/prasangka-dalam-konflikantar-etnik.html. Diunduh pada 5 Agustus 2012.

Myers, D. G. (1988). Social Psychology. Singapura: McGraw-Hill Book.

Puspa, T. (2011). Mbilung: Prasangka Masyarakat Jawa Transmigran terhadap Penduduk Lokal di Lampung. Skripsi. Surakarta: Universitas Muhammadiyah Surakarta.

Putra, I. E. (2012). Psikologi Prasangka, Sebab, Dampak, dan Solusi. Bogor: Penerbit Ghalia Indonesia.

Sarwono, S. W. (2002). Psikologi Sosial: Individu dan Teori-Teori Psikologi Sosial. Jakarta: Balai Pustaka.

Sarwono, S. W. (2007). Psikologi Prasangka Orang Indonesia: Kumpulan Studi Empirik Prasangka dalam Berbagai Aspek Kehidupan Orang Indonesia (Cetakan I). Jakarta: Raja Grafindo Persada.

Soeboer, R. (1990). Prasangka dan diskriminasi. Jurnal Psikologi Sosial, 4(3). 